\title{
A Post-Mortem Analysis of Privatisation in Cameroon: Fiscal and Structural Perspective
}

\author{
Alain V. Isoh ${ }^{1} \&$ Agnes Taylor ${ }^{2}$ \\ ${ }^{1}$ The university of Wales Institute, Cardiff School of Management \& London School of Commerce, UK. \\ ${ }^{2}$ The university of Coventry, UK \& London School of Commerce, UK. \\ Correspondence: Alain .V. Isoh, London School of Commerce, Chaucer House, White Hart Yard, London SE1 1NX, \\ United Kingdom.
}

Received: November 18, 2015

Accepted: December 8, $2015 \quad$ Available online: December 29, 2015

doi:10.11114/aef.v3i1.1270

URL: http://dx.doi.org/10.11114/aef.v3i1.1270

\begin{abstract}
Perhaps, it would sound profoundly erroneous to assumed a status quo of privatisation as a Post-mortem perspective considering that the scheme is largely incomplete. The current trends in the debate revealed no claim to reject the fact that there has been an insufficient initiative by the government of Cameroon to expedite the transfer of ownership of nationalised corporations as prescribed by the presidential ordinance of 1990 and 1994. In the midst of these diverse political and economic motivations, government resentment to privatise has been interpreted from varied standpoints. One thing is clear, privatisation in Cameroon has suffered unprecedented setbacks which perhaps has not only limited government participation in economic activities but is behind the policy objectives lines. This study is seemingly first of it kind to address the notion of ownership consciousness as a product of the dismal fiscal and structural outcomes of the privatisation process in Cameroon. With the used of multiple regression analysis, the results are statistically conclusive that changes in ownership of nationalised industries have not yet led to any significant fiscal gain both in the short-term and long-term perspective, but there is an overwhelmed influence by Private foreign investors as oppose to the much needed indigenised ownership in the appropriation of property rights in the privatised sector of Cameroon economy .
\end{abstract}

Keywords: Cameroon, Indeginised Ownership, Ownership Consciousness and Property rights

\section{Introduction}

\subsection{Emerging Issues}

If privatisation is the language of capitalism, then the novel economic order of private sector supremacy is the policy style on which contemporary economic system is anchored. Perhaps it is not strange to construe that privatisation is the 'holy grail' of free market economy, and the proposition of the Washington concensus on which the policy was fashioned is no longer a blueprint economic convention. There is a widespread understanding around the idea that the International Monetary Fund is currently perceived by many as a problematic institution. Evidence of lack of confidence from quite different perspectives including its intellectual orientation, and as well as the quality of its policy endorsements made to most developing economies are inevitably questionable (Frenkel, 2007).

At the time when Cameroon gained it political independence, the country was found facing an economy wherein industrial development was discouraged (Nzomo \& Nzongang, 2007). Over decades thereafter, major economic policies have practically evolved basically from import restrictions to price controls, and the participation of the new deal government in industry and commerce with the prospect of building a self-reliance economy (Hinman, 1994). The independent Cameroon created over 171 public enterprises funded mainly by government institutions such as the National Social Insurance Fund (CNPS), National Investment Fund (SNI) and the National Hydrocarbon Company (SNH) (Konings, 2004).

Until the dawn of 1970 economic growth was consistent at about 5\% per year in real terms (Tedonkeng, 2008). The twin effects of the petroleum boom between 1977/1978 and 1985/1986, together with the increased in exports of agricultural produce steered the economy to grow at an average of 7\% per year (Awung \& Atanga, 2011). With such great economic success stories, the country was portrayed as a model of Post-colonial independent economic powerhouse in Sub-Sahara Africa (Nzomo \& Nzongang, 2007).

In all, nationalised corporations created by the government were active in major areas of the economy as shown below: 
Table 1. Cameroon Public Sector

\begin{tabular}{|c|c|c|}
\hline YEAR OF CREATION & NAME OF COMPANY & ECONOMIC ACTIVITIES/SECTOR \\
\hline 1978 & CAMTEL & TELECOMMUNICATION \\
\hline 1976 & CNPS & SOCIAL SECURITY \\
\hline 1982 & SONARA & OIL AND GAS EXPLOITATION \\
\hline 1980 & $\mathrm{SNH}$ & HYDROCARBON \\
\hline 1999 & TRADEX & PETROLEUM DISTRIBUTION \\
\hline 2004 & CAMPOST & MAIL DELIVERY \\
\hline 1977 & CREDIT FONCIER & MORTGAGE FINANCE \\
\hline 1952 & SIC & REAL ESTATE \\
\hline 1977 & MAETURE & LAND DEVELOPMENT/MANAGEMENT \\
\hline 1974 & SODOCOTON & COTTON PRODUCTION/EXPORT \\
\hline 1947 & $\mathrm{CDC}$ & TEA, PALMS, BANANA PRODUCTION \\
\hline 1965 & CICAM & TEXTILE MANUFACTURING \\
\hline 1974 & SODECAO & COCOA PRODUCTION \\
\hline 2006 & CAMAIR-CO & AIRLINE \\
\hline 1957 & ALUCAM & ALUMINIUM \\
\hline 1963 & CIMEMCAM & CEMENT PRODUCTION \\
\hline 1987 & CRTV & RADIO AND TELEVISION \\
\hline 1986 & SONEL & ELECTRICITY \\
\hline 1973 & SNEC & WATER \\
\hline 1975 & HEVECAM & RUBBER \\
\hline 1975 & CAMSUCO & SUGAR \\
\hline 1976 & FEICOM & MUTUAL FUND \\
\hline 1969 & IMPRIMERIE NATIONALE & NATIONAL PRINTING PRESS \\
\hline 1977 & CEPER & EDITING AND PRINTING \\
\hline 1981 & ONDAPB & ANIMAL HUSBANDRY \\
\hline 1975 & SOFIBEL & FOREST EXPLOITATION \\
\hline 1966 & COCAM & FOREST EXPLOITATION \\
\hline 1984 & SCDM & METALLIC PRODUCTS \\
\hline 1975 & CHOCOCAM & PROCESSED FOOD \\
\hline 1971 & SEPBC & EXPLOITATION OF WOOD PRODUCTS \\
\hline 1975 & SOCAMAC & TRANSPORT AND "ACCONAGE \\
\hline 1968 & SEAC & MERCEDES REPRESENTATIVE \\
\hline
\end{tabular}

Source: Cameroon Institute for National Statistics

Events that led to the plummet in prices of major export products hastened the prominent 1986 financial crises (Tchoungui et al., 1995). Direct government subsidies to nationalised corporations soared to over 150 Billion FCFA in 1984, and the sequence of colossal spending continued to rise tremendously (Hinman, 1994).

The state of affairs evolved to the enactment of privatisation as a proposed panacea for the country's economic malaise which was very much similar to most developing economies of the Sub-Sahara economic region at that time (Kikeri \& Nellis, 2004). The policy of denationalisation was fashioned as a cornerstone of IMF lending criteria. It became a precedence with no exemptions as governments of most countries were forced to accord to IMF fiscal plan to secured financial assistance (Bouin, 1992). Supporting evidence of denationalisation indicated that any prospect of structural reform of State corporations without a change in the composition of ownership would be ineffective, and meaningless (Williamson, 1990; Berthélemy et al., 1994).Despite the massive turnaround of the ownership structure of the Cameroon public sector, the cumulative nature of Public sector debts, fiscal deficit and anaemic private sector investment are distinctive symptoms of the floundering features of the economy under the dominant influence of private sector ownership.

The impacts of privatisation in Cameroon remained largely unanswered and the anticipated private sector-led growth assumptions as suggested by the advocates of the bespoke policy of denationalisation have lost it overrated brilliance (Konings, 2003). The ultimate question requiring straightforward answers relate to the effectiveness of the policy instrument as the country is still under pressure to expedite the privatisation of the remaining nationalised corporations as endorsed by the IMF and the World Bank. The present-day statistics of Cameroon clearly depicts that public sector debts, fiscal deficits and unemployment are unprecedentedly high despite growth in real GDP. The question of the 
effectiveness of IMF policy tool of privatisation is apparently inevitable as the country still struggles to balance its fiscal equations both in the short term and long term periods.

Table1. Real GDP growth-Cameroon Economic Outlook

\begin{tabular}{lllllllllllll}
\hline YEAR & 2001 & 2002 & 2003 & 2004 & 2005 & 2006 & 2007 & 2008 & 2009 & 2010 & 2011 & 2012 \\
\hline REAL & $4.5 \%$ & $4 \%$ & $4 \%$ & $3.7 \%$ & $2.3 \%$ & $3.2 \%$ & $3.3 \%$ & $2.6 \%$ & $2 \%$ & $2.9 \%$ & $4.1 \%$ & $4.6 \%$ \\
GDP & & & & & & & & & & & & \\
GROWTH
\end{tabular}

Source: Cameroonian authorities and IMF staff

Table 2. Public Sector debts-Cameroon Economic Outlook

\begin{tabular}{lllll}
\hline Year & 2008 & 2009 & 2010 & 2011 \\
\hline Public debt & $9.5 \%$ & $10.6 \%$ & $12.1 \%$ & $12.9 \%$ \\
\hline
\end{tabular}

Source: Cameroonian authorities and IMF staff reports

Table 3. Fiscal deficit-Cameroon Economic outlook

\begin{tabular}{llllll}
\hline Year & 2008 & 2009 & 2010 & 2011 & 2012 \\
\hline Fiscal deficit & $2.3 \%$ & $-0.1 \%$ & $-1.1 \%$ & $-1.9 \%$ & $-3.9 \%$ \\
\hline
\end{tabular}

Source: Cameroonian authorities and IMF staff reports

The analysis of the problem of privatisation in Cameroon is based on key theoretical development including the well-thought stipulations of classical economics and free market system. The suggestions that ownership under the private sector is supreme to the public sector are just an indication that government ownership has no place in the contemporary economic system (Williamson, 1990). But, however, if the policy outcomes fall short of its objectives, then it is biassed to assumed that private sector ownership is a guaranteed for fiscal resilience.

That notwithstanding, selected ideas from classical economists further heightened the concern that ownership could be distinguished between the principal and agent (Alchian \& Demsetz, 1973). The proposition of agency theory is does considered significant when appraising ownership structure in public sector enterprises. Foremost in the debate on agency theory is the undulant relationship between the principal and the agents. The conflicting interests of stakeholders are the leading cause of agency problem (Hill \& Jones, 1992).

The application of agency theory in privatisation could be mirrored from three different positions. Firstly, an economy dominated by the private sector, secondly an economy dominated by the public sector, and lastly, an economy involving both private and public ownership. Taking the mix agency scenario as the starting point of the argument would mean the government and the private sector must act in a mutually corporative fashion by pursuing individual objectives and interest, but at the same time compromising on other stakeholders' interests to avoid conflicts of interests.

\subsection{Importance of the Problem}

The inconsistent fiscal position of Cameroon economy has necessitated a novel ideology to dichotomised the view that for privatisation to be effective, or perhaps considered optimal, then the supposition that both ownership structure and fiscal objectives should be prioritised bearing in mind that indeginised ownership is indispensable. In line with the aforementioned empirical substantiation, this study is aimed at analysing the effectiveness of privatisation in Cameroon in relations to the fiscal and structural impacts of the alteration of the ownership structure of nationalised industries. The intention of the researcher is neither to defend, nor to discard privatisation, but on the basis of statistics to highlight crucial macroeconomic components of the policy outcome of the paradigm.

Although series of expedient academic research had been devoted to privatisation notably that conducted by (Nellis, 2003; Berthélemy et al. 2004) mostly in the case of developing countries, it is worth mentioning that the context of the phenomenon has not been copiously uncovered in the case of Cameroon. Vital articles relating to the implementations of privatisation, and the performances of Cameroon public sector including those concluded by (Tchoungui et al. 1995; Konings, 1996, 2003; Nzomo \& Nzongang, 2007) are empirically inadequate.The proposition of indigenised ownership is long forgotten in the bigger picture of the evaluation of privatisation within the aforementioned articles with specific reference to the Cameroon economy.

This study is significant as it reveals a key aspect that would pioneer the driving force in the economic development of Cameroon as it suggests for the growth of indigenous investment would constitute the basis for creating an ethos of indigenous investments. 


\subsection{Propositions Of Privatisation}

Denationalisation as a policy tool was envisioned to restrain the rapid increase of government participation in public sector activities in Post-independence economies, with the intention to relieve the stress exerted by State-Owned Enterprises on public sector finance (Williamson, 1990).It was implemented as a strategy to encourage the growth of private sector investment in cooperation with indigenous entrepreneurs and foreign-based investors in Cameroon. The transfer of ownership became the nexus between the free market and capitalism as a cutting edge strategy to enhance private sector supremacy in developing economies. Nonetheless, considering the up-to-date economic outlook of Cameroon, it is evident to say that the expectations of the policy aftermaths are still far from completion. The growing concern of ownership consciousness is changing the paradigm of the transfer of ownership of public corporations to the private sector as many feels the policy objectives are far from being accomplished.

The novel phase of ownership consciousness as part of the policy evolution is intended to disentangle problems caused by privatised companies such as market failures. Regardless of the sluggish pace of denationalisation by the administration of Cameroon, the IMF and World Bank still uphold their position that the transfer of ownership is a prerequisite to extricate Cameroon underachieving public corporations (Konings,2003). The reality of the huge shift of public assets to the private sector of over 48 nationalised industries in Cameroon is far from achieving the objectives of the policy. The relationship between privatisation and growth in private sector investment, fiscal deficit and public sector debts is of increasing concern as the government is still holding absolute ownership of vital public sector enterprises.

\subsection{Research Hypotheses}

Based on the paradox of privatisation as highlighted by (Kay \& Thompson, 1986), the general statement of probability of this study can be construed to mean that privatisation has an adverse impact on public sector debts, fiscal deficit, and subsidies in Cameroon. It is consequently anticipated that the highlighted objectives of denationalisation are overwhelmed within the milieu of Cameroon economy as stated below.

H1: Privatisation and the size of Cameroon public sector debt are positively related.

$\mathrm{H} 2$ : Privatisation and the size of public sector subsidies are directly related.

H3: Cameroon public sector deficit would increase in the event of denationalisation.

H4: Privatisation and indigenised ownership are inversely related

\section{Methodology}

\subsection{Methodological Issues Involved}

In the history of structural adjustment analyses, there are profound methodological questions that need to be endured when considering venturing into assessing the effects of adjustment issues (Easterly, 2005). First, there is the counterfactual issue that highlights the question of what would have happened without adjustment? Another aspect is the 'before and after' approach that assessed the impact of the reforms on economic performance before adjustments are made, and then compares them with Post-adjustment performance (Khan et al.,2011).The associated differences are often attributed to the effects of the adjustment programme of the implementing country. The 'with' and 'without' approach popularly known as Control group method involves comparing the performance of groups of adjusting countries to those of non-adjusting countries (Khan et al., 2011). The main problem with this approach is that there are variations in the actual adjustment packages and the reforms implemented by these countries (Ahmed \& Lipton, 1997).

Another impact using this approach is the concern that no two economies are the same as they would definitely response differently to the same adjustment package thus making the comparison process unfair. It is well-known that not all the implementing countries share a common socio-economic and political attributes. To a greater extent, this disparity determines the pace of acceptance and adoption of privatisation in most developing countries (Gore,2000; Berthélemy et al.,2004). The idea of using the counterfactual approach as a standardised analytical method is problematic considering that the macroeconomic variables are prone to changes that are largely unprecedented and inconclusive (Khan et al., 2011). In the case of assessing the impact of privatisation in Cameroon, the counterfactual approach may not provide concise answers to the questions of the effectiveness of the policy outcome. Therefore, the question of what would have happened without adjustment becomes doubtful and bias.

The understanding of the macroeconomic environment without adjustment is complex, and the used of assumptions to create a scenario of without adjustment may be based on predispositions which apparently are faulty. Further substantiation indicates that the economic environment is highly volatile and the risk of speculation may jeopardise the analysis. The researcher has no control over research variables and, therefore, the 'with or without approach' is irrelevant to the study. The "before and after" approach unrealistically assumed that all else is equal which is prone to severe methodological problems (Bouin, 1992). Likewise, the problem of authenticity, relevant and accuracy of the data 
collection always come up since this method relied upon historical data observed by someone other than the researcher (Daniel \& Sam, 2010).

The alternative method commonly used is the "without approach". This method compares countries with adjustment programmes and those without any adjustment programmes (Khan, 2008).It assumed that countries requiring IMF plans were similar to countries that do not need them. It is based on doubtful assumptions mainly because selection bias may be involved in determining which countries require IMF programmes, and which countries do not need such structural reforms (Khan et al., 2011).The problem of such generalisation may be reflected in the heterogeneity of social and political discrepancy. In most cases, IMF programmes ignore to consider this disparity before the implementation of it economic plans.

However, the most accurate way of evaluating the effectiveness of privatisation was proposed by World Bank.It involves comparing privatisation proceeds over time to observed GDP by the implementing countries (Clifton et al., 2003). This is preferred as a better indicator than using proceeds per inhabitant as it reflects huge differences in income per inhabitant. Another technique of evaluating privatisation is by examining the coefficient between the accumulated privatisation proceeds and the size of the public sector enterprise before the commencement of the privatisation process. But yet, the results are much more mixed and are partly explained by financial markets trends that make the assessment of privatisation based on proceeds quite challenging (Clifton et al., 2003).

\subsection{Methodological Design}

The most appropriate methodological design for this study is the concurrent approach. The premise that necessitate this plan is prompted by the proposition that the transfers of ownership of key public sector corporations in Cameroon are mostly incomplete. Cameroon is far behind the policy enforcement line of the privatisation of public enterprises.

The statistical implications of this paradigm are that the results of the analysis are valid only within the specified period of the study, and it does not provide enough statistical suggestions to generalise the policy outcomes in relation to other countries that have implemented the model over the years. The intention of the researcher is to provide rooms for unexpected changes in economic and political decisions that may trigger either positive or negative changes in the results of the paradigm in the future.

It is imperative to know that by the concurrent approach, results must be referred based on time and space. The validity of the analysis represents the period from 1994-2012 in the case of Cameroon. The concurrent approach provides a new perspective in assessing privatisation as a work-in-progress. Results of this nature indicate that conclusions are not finite, but most reflect elements of time and place. The propositions of the concurrent model deviate from the generalisation in both longitudinal and cross-sectional fashion. What works in one country may not work for others or, what works today may not work tomorrow. Such understanding is prudent and provides a base for policy argumentation.

Taking into consideration the above methodological differences, the IMF policy of privatisation in the case of Cameroon is measured by statistically testing Privatisation proceeds and Private sector taxable revenue with specific reference to Public sector subsidies, Public sector debts and Public sector deficits using the econometric tool of multiple regression from 1994-2012.The expected outcomes of the statistical testing of research hypothesis provide point estimate that approximates the resulting impacts of the policy on the identified research variables as mentioned above.

\subsection{Description of the Analytical Technique Used.}

The conceptual framework of the study is interpreted to mean that the policy instruments of privatisation are essentially the leading cause of the country fiscal instability and the rising trends of public sector subsidies in Cameroon. The policy instrument of privatisation has not yet generated the expected benefits of private sector ownership over the underperforming dominance of public sector investments. Statistically, the above notion could be expressed as thus:

The expression $\mathrm{Y} x$; ( $\mathrm{y} x)$ relates to the dependent and explanatory functions of the policy instrument of privatisation. This could be further symbolised in its simplest form as $\mathrm{y}=\mathrm{f}$ (xi) representing a straight line function(s) of relationships between the cause-effects variables that could be interpreted as: $Y=a+b x+e$; Where $\mathbf{a}$ is an autonomous estimate,b is the linear coefficients of the function, $\mathbf{e}$ is the random error and term " $x$ " represents the explanatory variable. The variable $\mathbf{y}$ in the equation represents the policy outcome of the adjustment programme that relates to the dependent variables under observation.

The individual functional terms of the model are mathematically expressed as:

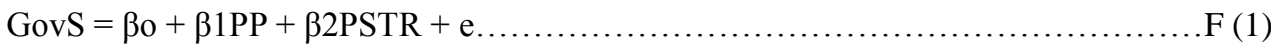

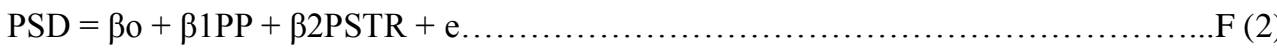

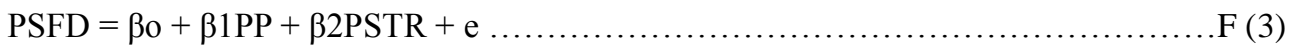

Where; 
PSD (Public sector debts)

PSFD (Public sector fiscal deficit)

GovS (Government subsidies)

Based on empirical evidence, the most appropriate variables to comprehend the impact of privatisation on fiscal deficit and public sector debts would be expressing privatisation as Private sector taxable revenue (PSTR) and Privatisation proceeds (PP) in the period of privatisation based on the assumption that Privatisation proceeds and Private sector taxable revenue are both used in servicing Public sector debts and Public sector subsidies with specific reference to the Cameroon economy.

\section{Findings}

\subsection{Structural Implications}

The fundamental question to be unravelled by this objective is anchored on the quest for indigenised ownership. The understanding of optimal ownership distribution is defined by the permutation of shares of former nationalised corporations to include Private foreign investors, Private local investors, and the Government of Cameroon. Resentment to privatisation has often been fueled by changes in the direction of ownership of public corporations. This may not necessarily have a direct economic or intellectual impact but could pose profound influence on the ideological perception of the policy framework as changes in ownership would compromise nationalistic feelings (Bethelemy et al., 2004). The debacle of ownership paradigm in privatisation lies in the depth of property rights and agency theories. The ownership structure and motive of privatisation varied, and there are no standard approaches to defining the brilliance of economic and development strategies (Stiglitz, 1998).

To a significant extent, denationalisation determines the destination of the economy as a whole. By implication, an economy dominated by Public sector ownership would strengthen the controlling interest of the government while, Private ownership superiority would means significant powers would be given to the private sector, and would influence the way the economic works. Agency theory suggests that agents have multifarious objectives and interests that often result to the agency problem due to conflict of individual stakeholders' interests (Alchian \& Demsetz, 1973). The excessive influence of the private sector has always been a potential threat to government participation in industry and commerce, and the rise in ownership consciousness by indigenous investors.

The impression of indigenised ownership emerged from the proposition of ownership consciousness influenced by the inadequacy of indigenous participation in the privatisation process of nationalised industries in Cameroon. It is aimed at giving indigenous entrepreneurs and the local government the edge in the ownership and control priority over foreign investors to narrow foreign supremacy over domestic ownership. The supposition of indigenisation is in no way aimed to restrain private sector investment, but to ensure that the sum of government ownership and local entrepreneurs' participations surpasses the proportion of foreign ownership in the privatised sector of Cameroon economy.
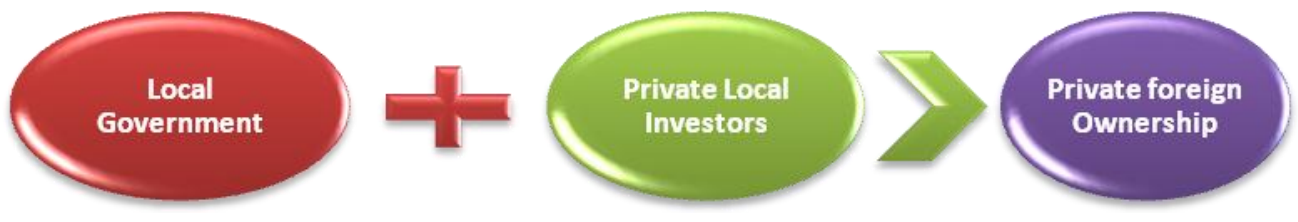

Figure1. Structure of indigenous ownership

Source: Author's postulation

Notwithstanding, empirical evidence of the nomenclature of privatisation in Cameroon is as shown in the table below:

Table 4. Nomenclature of privatisation in Cameroon

\begin{tabular}{llllll}
\hline YEAR & COMPANY & Activities & $\begin{array}{l}\text { Gov. of Cameroon } \\
(\%)\end{array}$ & $\begin{array}{l}\text { Private } \\
\text { ownership (\%) }\end{array}$ & $\begin{array}{l}\text { Local } \\
\text { ownership (\%) }\end{array}$ \\
1991 & OCB/OSB & Agro-industrial & 0 & 30 & 70 \\
1991 & CHOCOCAM & Cocoa industry & 0 & 25.3 & 74.7 \\
1998 & CAMSUCO & Agro-industrial & 0 & 0.05 & 98.1 \\
1999 & SOCAPALM & Agro-industrial & 10 & 90 & 0 \\
1993 & CAMSHIP & Container terminals & 0 & 41 & 51 \\
1998 & CEPER & Printing and publication & 0 & 100 & 0 \\
1992 & ONDAPA/YAOUNDE & Poultry & 0 & 66 & 34 \\
1974 & SODECOTON & Cotton & 59 & 41 & 0 \\
& & & & & \\
\hline
\end{tabular}




\begin{tabular}{llllll}
\hline 1996 & HEVECAM & Agro-industry & 10 & 0 & 90 \\
2001 & SONEL-AES-SONEL & & 44 & 0 & 56 \\
2006 & CAMWATER & Water & 100 & 0 & 0 \\
1987 & CRTV & Radio and television & 100 & 0 & 0 \\
2004 & CAMPOST & Postal services & 100 & 0 & 0 \\
1978 & CAMTEL-FIXED & Communication & 100 & 0 & 0 \\
2006 & CAMAIR-CO & Airline transport & 100 & 0 & 0 \\
1976 & CNPS & National social insurance & 100 & 0 & 0 \\
1980 & SNH & Hydrocarbon & 100 & 0 & 0 \\
1977 & CFC & Building society & 100 & 0 & 53.3 \\
1957 & ALUCAM & Aluminium & 46.7 & 0 & 57 \\
1963 & CIMENCAM & Cement & 43 & 0 & 51 \\
1991 & SOCAMAC & Harbour Handling & 53.51 & 0 & 70 \\
1991 & SEPBE & Forest Reserve & 0 & 0 & 87.6 \\
1992 & COCAM & Plywood & 0 & 0 & 86.6 \\
1994 & SCDM & Metallurgy & 0 & 0 & 81.2 \\
1999 & CAMRAIL & Railways & 13.5 & 5.3 \\
1998 & BICEC & Banking & 17.5 & 7.5 & 70 \\
2001 & CAMTEL-MOBILE & Telecommunication & 0 & 30 & 72.75 \\
1995 & SPFS-SRL & Agro-industrial & 0 & 27.25 & 0 \\
1995 & SOFIBEL & Forestry & 0 & 79.43 & \\
\hline
\end{tabular}

Source: Cameroonian authorities and IMF staff reports

Based on the above structure of privatisation, the following proportion of ownership is appropriated accordingly.

Table 5. Appropriation of ownership structure

\begin{tabular}{lll}
\hline Government of Cameroon & Private local investors & Private foreign investors \\
\hline $14.9 \%$ & $27 \%$ & $58.1 \%$ \\
\hline
\end{tabular}

Source: Author's estimate

The aforementioned tabulations indicate that Private foreign investors dominate ownership of over $58 \%$ of Cameroon privatised sector of the economy from 1994-2012, thereby making indigenous investors out of ownership priority.

Following the sluggish response to debts sustainability, the privatisation of the country's major corporations are seemingly far from achieving their respective completion deadline targets and as such, the question of indigenised ownership is not only projecting a retardation in the policy enforcement, but the idea that more need to be done to address ownership priority and financial motive as a twin objectives of denationalisation within the Cameroon context. This result is significant as it portrays an alternative trajectory of privatisation to revamp the ethos of domestic investment rather than an absolute transfer of ownership which is indispensable in achieving the anticipated status of an emerging economy by 2035 .

\subsection{Fiscal Impact}

\subsection{1econometric Model of Regression Analysis}

The analysis of the impact of privatisation on public sector debts and fiscal deficit in Cameroon follows an econometric model of multiple regressions. As already highlighted, the policy proposition of privatisation relates to the claims by IMF-supported by the Washington consensus of 1990 (Williamson,1990). It assumed that the transfer of ownership of State-owned enterprises to the private sector was aimed to stimulate economic growth and enhanced a sound fiscal situation of the struggling economy.

In other words, private sector investment is outstanding to the inferior government ownership (Berthélemy et al., 2004). The premise of this research is based on the postulation that the objective of fiscal stability of the transfer of property rights has been defeated in the case of Cameroon. The following review is the step-by-step procedure of the analysis of these claims. The research period under consideration is from 1994 to 2012. Key explanatory variables to ascertain these propositions include Privatisation proceeds (PP) and Private sector taxable revenue (PSTR) as shown below. 
Table 5. Assessing the leveraging effects of privatisation proceeds on debts and subsidies

\begin{tabular}{|c|c|c|c|c|c|c|c|}
\hline \multirow[t]{3}{*}{ Year } & \multirow{3}{*}{$\begin{array}{l}\text { PROCEEDS } \\
\text { Billion FCFA }\end{array}$} & \multirow{3}{*}{$\begin{array}{l}\text { DEBT } \\
\text { Billion } \\
\text { FCFA } \\
\end{array}$} & \multicolumn{2}{|c|}{ LEVERAGE ON } & \multirow{3}{*}{$\begin{array}{l}\text { SUBSIDIES } \\
\text { Billion } \\
\text { FCFA } \\
\end{array}$} & \multicolumn{2}{|c|}{ LEVERAGE ON } \\
\hline & & & DEBTS & Billion & & SUBSIDIES & Billion \\
\hline & & & FCFA & & & FCFA & \\
\hline 1994 & 0 & 152.7 & -152.7 & & 57 & -57 & \\
\hline 1995 & 1 & 633.0 & -631 & & 77 & -76 & \\
\hline 1996 & 22 & 74.8 & -52.8 & & 63 & -41 & \\
\hline 1997 & 1 & $\mathrm{n} / \mathrm{a}$ & $\mathrm{n} / \mathrm{a}$ & & 85 & -84 & \\
\hline 1998 & 11 & $\mathrm{n} / \mathrm{a}$ & $\mathrm{n} / \mathrm{a}$ & & 100 & -89 & \\
\hline 1999 & 79 & 302 & -223 & & 109 & -30 & \\
\hline 2000 & 0 & 339 & -339 & & 133 & -133 & \\
\hline 2001 & 0 & 917 & -917 & & $\mathrm{n} / \mathrm{a}$ & $\mathrm{n} / \mathrm{a}$ & \\
\hline 2002 & 2 & 914 & -912 & & 113 & -111 & \\
\hline 2003 & 0 & 313 & -313 & & 129 & -129 & \\
\hline 2004 & 8 & 285 & -277 & & 141 & -133 & \\
\hline 2005 & 0 & 4,534 & -4.534 & & 175 & -175 & \\
\hline 2006 & 0 & 1,489 & $-1,489$ & & 211 & -211 & \\
\hline 2007 & 0 & 1,171 & $-1,171$ & & 230 & -230 & \\
\hline 2008 & 0 & 1,015 & $-1,015$ & & 286 & -286 & \\
\hline 2009 & 0 & 1,114 & $-1,114$ & & 289 & -289 & \\
\hline 2010 & 0 & 1,349 & $-1,349$ & & 331 & -331 & \\
\hline 2011 & 0 & 1,663 & $-1,663$ & & 550 & -550 & \\
\hline 2012 & 0 & 2,085 & $-2,085$ & & 426 & -426 & \\
\hline
\end{tabular}

Source: Cameroon authorities, IMF staff and author's computation

Table 6. Long-term leveraging effects

\begin{tabular}{lllllll}
\hline YEAR & \%TAX & TOTAL & TAX & PRIVATE & PUBLIC & LONG TERM \\
OF & REVENUE & REVENUE & REVENUE & SECTOR & DEBT & LEVERAGING \\
TRANSACTIONS & BILLION & BILLION & BILLION & REV & BILLION & EFFECTS \\
& FCFA & FCFA & FCFA & AS \%PGFI & FCFA & BILLION \\
& & & & BILLION & & FCFA \\
& & & & FCFA & & \\
\hline 1994 & 71.7 & 534 & 382.9 & 354.6 & 152.7 & 201.9 \\
1995 & 68.9 & 654 & 450.6 & 435.7 & 633.0 & -198.7 \\
1996 & 65.3 & 723 & 472.1 & 441.9 & 74.8 & 367.1 \\
1997 & 68.1 & 863 & 587.7 & 519.5 & N/A & N/A \\
1998 & 77.8 & 848 & 659.7 & 577.9 & N/A & N/A \\
1999 & 64.7 & 1,092 & 706.5 & 646.4 & 302 & 344 \\
2000 & 72.5 & 1,110 & 804.7 & 709.7 & 339 & 370.7 \\
2001 & 66.2 & 1,220 & 807.6 & 694 & 917 & -223 \\
2002 & 94.6 & 1,325 & $1,253.4$ & 1,108 & 914 & 194 \\
2003 & 94.8 & 1,405 & $1,331.9$ & $1,157.4$ & 313 & 844.4 \\
2004 & 92.4 & 1,267 & $1,170.7$ & $1,009.1$ & 285 & 724.1 \\
2005 & 91.9 & 1,543 & 1,418 & $1,175.5$ & 4,534 & $-3,359.5$
\end{tabular}




\begin{tabular}{lllllll}
2006 & 94.5 & 1,808 & $1,708.6$ & $1,433.5$ & 1,489 & -55.5 \\
2007 & 13.8 & 1,867 & 1,236 & $9,71.5$ & 1,171 & -199.5 \\
2008 & 12.3 & 2,122 & 810 & 562 & 1,015 & -453 \\
2009 & 12.7 & 1,839 & 1,331 & $1,020.8$ & 1,114 & -93 \\
2010 & 12.4 & 1,940 & 1,375 & 1,024 & 1,349 & -325 \\
2011 & 12.9 & 2,250 & 1,551 & 1,039 & 1,633 & -594 \\
2012 & 13.5 & 2,370 & 1,677 & $1,174.7$ & 2,085 & -910 \\
\hline
\end{tabular}

Source: Author's computation

\section{A. PUBLIC SECTOR SUBSIDIES:}

Analysis of the above figures using multiple regressions analysis shows the following outputs of the data set with specific reference to Public sector subsidies using Privatisation proceeds and Private sector taxable revenue as standard explanatory variables.

Table 7. Regression output on subsidies

\begin{tabular}{lllllllll}
\hline & Coefficients & $\begin{array}{l}\text { Standard } \\
\text { Error }\end{array}$ & t-Stat & P-value & $\begin{array}{l}\text { Lower } \\
95 \%\end{array}$ & $\begin{array}{l}\text { Upper } \\
95 \%\end{array}$ & $\begin{array}{l}\text { Lower } \\
95.0 \%\end{array}$ & $\begin{array}{l}\text { Upper } \\
95.0 \%\end{array}$ \\
\hline Intercept & 14.09398 & 75.5757 & 0.186488 & 0.854406 & -146.119 & 174.3073 & -146.119 & 174.3073 \\
PRIV TAX & 0.191114 & 0.081386 & 2.348234 & 0.032047 & 0.018583 & 0.363645 & 0.018583 & 0.363645 \\
PROCEEDS & -0.59433 & 1.390662 & -0.42737 & 0.674806 & -3.5424 & 2.353746 & -3.5424 & 2.353746
\end{tabular}

The regression outputs for Public sector subsidies are statistically conclusive. It indicates that the proportion of the variability of subsidies caused by changes in Public sector taxable revenue, and Privatisation proceeds as represented by the coefficient of determination R Square is just $20 \%$ at the $95 \%$ confidence interval as shown in appendix A. This estimation specifies that Privatisation proceeds and Private sector taxable revenue can accurately explain only $20 \%$ of changes in subsidies within the period of analysis.

The 'good fit' for the regression analysis according to regression output as contained in appendix A is 0.062 which is greater than the threshold of 0.05 . Somehow, this compromises the accuracy of this regression model to ascertain the fact that Privatisation proceeds and Private sector taxable revenue do not satisfactorily explained the variability in Public sector subsidies.

The significance of the regression analysis on Public sector subsidies resulted in the rejection of the claim by IMF that private sector investments are expected to generate enough revenue to lessen aggregate Public sector subsidies. Statistical computations present evidence to suggest that the privatisation of Cameroon public corporations has failed to reduce the size of the country public sector subsidies at P-value of 0.032 . This analysis, therefore, agrees to the alternative proposition which correspond to the researcher's claim. The predictive analysis as established by the correlation coefficient of Private sector taxable revenue of 0.191 indicates that an increase by 1 billion FCFA of Private sector taxable revenue would lead to a rise by 191 million FCFA of Public sector subsidies considering that Privatisation proceeds are held constant.

On the other hand, Privatisation proceeds are extensively insignificant at P-value of 0.67 to discard the claim that privatisation proceeds can lessen subsidies as shown in appendix A. However, this implies that we do not reject nor accept IMF proposition of Privatisation proceeds to enhance subsidies as the probability of this estimate is very insignificant to make statistical inference with regards to privatisation proceeds.

B. PUBLIC SECTOR DEBTS (PSD):

The next dependent variable in the analysis is public sector debts (PSD). The regression outcomes of the statistical inputs of the established data set for Public sector debts are as follows:

Table 8. Regression outputs for Public sector debts

\begin{tabular}{lllllllll}
\hline & Coefficients & $\begin{array}{l}\text { Standard } \\
\text { Error }\end{array}$ & $t$-Stat & P-value & $\begin{array}{l}\text { Lower } \\
95 \%\end{array}$ & $\begin{array}{l}\text { Upper } \\
95 \%\end{array}$ & $\begin{array}{l}\text { Lower } \\
95.0 \%\end{array}$ & Upper 95.0\% \\
\hline Intercept & -546.616 & 651.1447 & -0.83947 & 0.413574 & -1926.98 & 833.7493 & -1926.98 & 833.7493 \\
PRIV TAX & 1.839117 & 0.701208 & 2.622784 & 0.018465 & 0.352623 & 3.325611 & 0.352623 & 3.325611 \\
PROCEEDS & -6.664 & 11.98166 & -0.55618 & 0.58578 & -32.064 & 18.73598 & -32.064 & 18.73598 \\
\hline
\end{tabular}


The variability in Public sector debts caused by changes in Privatisation proceeds and Private sector taxable revenue as indicated by the coefficient of determination R-square is just 35\% (see appendix B).This means that Privatisation proceeds and Private sector taxable revenue can explain only 35\% of the changes in Public sector debts at $95 \%$ confidence interval. The 'good-fit' of the accuracy of this regression is significant as both Privatisation proceeds and Private sector taxable revenue accurately explained the variability of Public sector debts at 0.033 . The significance of this regression indicates that Private sector taxable revenue is actively momentous to reject IMF claims that private sector investment can generate enough taxable revenue to offset Cameroon Public sector debts.

Also, the coefficient of regression indicates that an increase by 1 Billion FCFA of Private sector taxable revenue would lead to a rise in Public sector debts by 1.839 billion FCFA. Meanwhile on the basis of Privatisation proceeds, the regression analyses of the variables indicate that Privatisation proceeds do not provide enough evidence to reject nor accept IMF claim that Privatisation proceeds can enhance Public sector debts. This implies that Privatisation proceeds are irrelevant at P-value of 0.58578 to dismiss the claim that Privatisation proceeds can improve Public sector debts.

C. PUBLIC SECTOR DEFICIT:

The final variable of our analysis is Public sector deficit. The regression outputs for public sector deficit represent the following:

Table 9. Regression output for Public sector deficits

\begin{tabular}{|c|c|c|c|c|c|c|c|c|}
\hline & Coefficients & $\begin{array}{c}\text { Standard } \\
\text { Error }\end{array}$ & $t$-Stat & $P$-value & $\begin{array}{c}\text { Lower } \\
95 \%\end{array}$ & $\begin{array}{c}\text { Upper } \\
95 \%\end{array}$ & $\begin{array}{l}\text { Lower } \\
95.0 \%\end{array}$ & $\begin{array}{l}\text { Upper } \\
95.0 \%\end{array}$ \\
\hline Intercept & -233.952 & 114.1161 & -2.05012 & 0.05711 & -475.867 & 7.963612 & -475.867 & 7.963612 \\
\hline PRIV TAX & -0.00023 & 0.12289 & -0.00188 & 0.998523 & -0.26075 & 0.260284 & -0.26075 & 0.260284 \\
\hline PROCEEDS & 3.264478 & 2.099841 & 1.554631 & 0.13959 & -1.18699 & 7.715943 & -1.18699 & 7.715943 \\
\hline
\end{tabular}

The variability of Public sector deficit that can be explained by Privatisation proceeds and Private sector taxable revenue is just $3 \%$, and the 'good-fit' of the regression is 0.302 as shown in appendix $\mathrm{C}$. This suggests that the accuracy of the explanatory variable is highly inadequate to provide any concise meaning to the variability in public sector deficit. Yet, We cannot rely on Privatisation proceeds and Private sector taxable revenue as the best set of explanatory variables of Public sector deficit. The level of significance at 95\% confidence interval for both Private sector taxable revenue and Privatisation proceeds are highly trivial at 0.998 and 0.139 of P-value.This does not provide statistical evidence to discard the claim that Privatisation proceeds and Private sector taxable revenue can reduce Public sector deficit.We can not accept or reject IMF claim on deficit reduction on the basis of regression statistics.

\section{Conclusion and Recommendations}

The Post-mortem analysis of privatisation agenda in Cameroon as revealed by this study indicate that the proportion of Private foreign ownership exceeds those of Private local and Government ownership in the privatised sector of Cameroon economy.The proposition of fiscal stability as indicated by the IMF failed the litmus test as privatisation proceeds is proven to be insignificant to enhance a healthy fiscal outlook of Cameroon economy. The claim of growth in private sector investment and its cumulative impact on private sector taxable revenue is proven to be ineffective making the country still indebted and fiscally fragile. It is no surprise to say the policy attempt of privatisation in Cameroon was entirely based on wishful thinking. The set pieces of the current fiscal situations are evidence.

Following the sluggish response to debts sustainability, the privatisation of the country's major corporations are seemingly far from achieving their respective completion deadline targets, and as such the question of indigenisation is not only projecting a retardation in policy enforcement but the idea that more need to be done to address ownership priority and financial motive as twin objectives of denationalisation in the Cameroon context . Considering these statistical and empirical deductions, we recommend that the government of Cameroon should extend the privatisation agenda, but must provide for the participation of Local private investors and government ownership.The condition to encourage an ethos of local ownership must be supported by an increase in the investment in human capacity to be competitive.

\section{References}

Amed, I. I., \& Lipton, M. (1997). The Impact of Structural Adjustment on Sustainable Rural Livelihoods: A Review of the Literature. Institute of Development Studies and Poverty Research Unit-IDS, Working Paper 62. Pp. 1-33.

Alchian, A. A ., \& Demsetz, H. (1973).The Property Right Paradigm. The Journal of Economic History, 33(1), 16-27.

Amungwa, F. A. (2009). Appraisal of Privatisation of Agricultural Extension Services in Cameroon. Journal of Agricultural Extension and Rural Development, 1(3), 085-092.

Awung, W. J., \& Atanga, M. (2011). The Economic crisis and multiparty politics in Cameroon. Cameroon Journal of Democracy and Human Rights- CJDHR., 5(1), 94-127.

Berthélemy, J. et al. (2004). Privatisation in Sub-Saharan Africa: Where Do We Stand? .Paris: Development Centre of 
the Organisation for Economic Co-Operation and Development-OECD.

Bouin, O. (1992). The Privatisation in Developing Countries: Reflections on a Panacea. Brief, 3. Paris: Development Centre Policy OECD.

Clifton, J. et al. (2003). Privatisation in the European Union: Public Enterprises and Integration. Dordrecht: Kluwer Academic Publishers.

Daniel, S., \& Sam, A. G. (2010). Research Methodology. Delhi: Kalpaz publication.

Easterly, W. (2005). What Did Structural Adjustment Adjust? .The Association of Policies and Growth with Repeated IMF and World Bank Adjustment Loans, 76, 1-22.

Frenkel, R. (2007). Current problems with the IMF and Challenges Ahead: A Latin American Perspective. FES briefing, December 2007, 16, 2-7.

Gore, C. (2000). The Rise and Fall of the Washington Consensus as a Paradigm for Developing Countries. World Development, 28(5), 789-804,

Hinman, D. L. (1994). Implementation of the World Bank's First Structural Adjustment Loan in Cameroon: A Case Study of Public Enterprise Reforms and Industrial and Commercial Reforms Decentralization: Finance and Management Project Associates In Rural Development, Inc. The United States Agency for International Development Mission to Cameroon Office of Economic Analysis and Policy Reform Implementation.

Hutcheson, G. D. (2011). Ordinary Least-Squares Regression. The SAGE Dictionary of Quantitative Management Research, 224-228.

Hill, C. W. L., \& Jones, T. M. (1992). Stakeholders -Agency Theory. Journal of Management Studies, 29(2), 131-154.

IMF Country Report. (2006). IMF Cameroon: Poverty Reduction Strategy Paper. Third Annual Progress Report Washington DC: IMF Publication.

International Monetary Fund. (2013). Cameroon 2013 Article IV consultation. IMF Country Report, Washington DC: International Monetary Fund Publication Services.

International Monetary Fund. (2006) .IMF Country Report No. 06/260 Cameroon: Poverty Reduction Strategy Paper. $3^{\text {rd }}$ Annual Progress Report. Washington DC: IMF secretary department release.

International Monetary Fund. (2012). Cameroon 2012 Article IV consultation IMF country report. no.12/237. Washington DC: IMF publication.

International Monetary Fund. (2014). Factsheet of Cameroon economic profile. Washington. D.C: IMF Secretary's Department.

Kay, J. A., \& Thompson, D. J. (1986). Privatisation: A Policy In Search Of a Rationale. Economic Journal, 96, 18-32.

Khan et al.(2011). Impact Evaluation of Structural Adjustment Program: A Case of Pakistan. European Journal of Economics, Finance and Administrative Sciences, 29, 52-62.

Khan, J. A. (2008).Research methodology. New Delhi: APH Publishing Corporation.

Kikeri, S., \& Nellis, J. (2004). An Assessment of Privatisation. The World Bank Research Observer, 19(1), 87-118.

Konings, P .(2003).Privatisation And Ethno-Regional Protest In Cameroon. Africa Spectrum, 38(1), 5-26.

Konings, P. (1996). The Post-Colonial State and Economic and Political Reforms in Cameroon', In A.E. Fernández Jilberto \& A. Mommen (Eds), Liberalization in the Developing World: Institutional and Economic Changes In Latin America, Africa and Asia. London: Routledge.

Konings, P. (1996). Privatisation of Agro-Industrial Parastatal and Anglophone Opposition in Cameroon. Journal of Commonwealth and Comparative Politics, 34, 199-217.

Nellis, J. (2005). Privatisation in Africa: What has happened? What is to be done? Centre for Global Development. $127(5), 1-44$.

Nellis, J. (2006). Back to the Future for African Infrastructure? Why state-ownership is no more promising the second time around. Working Paper No. 84.Washington DC: Centre for Global Development.

Nzomo, J. T., \& Nzongang, J. (2007). The process of privatisation of public and Para-public enterprises in Cameroon: An assessment. Journal of sustainable development in Africa, 9(4), 229-246.

Stiglitz, J. E. (1998). More Instruments and Broader Goals: Moving Toward the Post -Washington Consensus 1998.UNU World Institute for Development Economics Research, 2, 1-39.

Tchoungui et al. (1995).Structural Adjustment and Sustainable Development in Cameroon. Overseas Development Institute-ODI. Working Paper, 83, 1-130.

Williamson, J. (1990). What Washington Means By Policy Reform. Peterson Institute for International Economics. 


\section{Appendix}

Appendix A: Summary Outcome Subsidies

\begin{tabular}{ll}
\hline Regression Statistics & \\
\hline Multiple R & 0.541304 \\
R Square & 0.29301 \\
Adjusted R Square & 0.204636 \\
Standard Error & 105.1277 \\
Observations & 19 \\
\hline
\end{tabular}

\begin{tabular}{llllll}
\hline ANOVA & & & & & \\
\hline & $D f$ & $S S$ & $M S$ & $F$ & Significance \\
& & & & & $F$ \\
Regression & 2 & 73286.38 & 36643.19 & 3.315576 & 0.062418 \\
Residual & 16 & 176829.3 & 11051.83 & & \\
Total & 18 & 250115.7 & & & \\
\hline
\end{tabular}

Appendix B: Summary Output for Debts

\begin{tabular}{ll}
\hline & \\
\hline Regression Statistics & \\
Multiple R & 0.588368 \\
R Square & 0.346177 \\
Adjusted R Square & 0.264449 \\
Standard Error & 905.7586 \\
Observations & 19 \\
\hline
\end{tabular}

\begin{tabular}{lrrrrr}
\hline ANOVA & \multicolumn{1}{c}{ SS } & \multicolumn{1}{c}{ MS } & \multicolumn{1}{c}{ Significance $F$} \\
& Df & & \multicolumn{1}{c}{ S } & \\
Regression & 2 & 6949980 & 3474990 & 4.235733 & 0.033395 \\
Residual & 16 & 13126379 & 820398.7 & & \\
Total & 18 & 20076358 & & & \\
\hline
\end{tabular}

Appendix C: Summary Output for Deficit

\begin{tabular}{ll}
\hline Regression Statistics & \\
\hline Multiple R & 0.372904 \\
R Square & 0.139057 \\
Adjusted R Square & 0.031439 \\
Standard Error & 158.7384 \\
Observations & 19 \\
\hline
\end{tabular}

\begin{tabular}{llllll}
\hline ANOVA & & & & & \\
\hline & $D f$ & $S S$ & $M S$ & $F$ & Significance \\
& & & & & $F$ \\
Regression & 2 & 65118.38 & 32559.19 & 1.29214 & 0.301852 \\
Residual & 16 & 403166.1 & 25197.88 & & \\
Total & 18 & 468284.5 & & & \\
\hline
\end{tabular}

\section{(cc) EY}

This work is licensed under a Creative Commons Attribution 3.0 License 